\title{
MANFAAT LATIHAN OLAHRAGA AEROBIK TERHADAP KEBUGARAN FISIK MANUSIA
}

\author{
Chrisly M. Palar \\ Djon Wongkar \\ Shane H. R. Ticoalu
}

\begin{abstract}
${ }^{1}$ Kandidat Skripsi Fakultas Kedokteran Universitas Sam Ratulangi Manado
${ }^{2}$ Bagian Anatomi Histologi Fakultas Kedokteran Universitas Sam Ratulangi

Email: chrislypalar@yahoo.com
\end{abstract}

\begin{abstract}
Aerobic exercise is a kind of exercise systematically by increasing the load gradually and continuously using energy derived from the combustion using oxygen, and takes oxygen without causing fatigue. Examples of aerobic exercise is the way, jogging, running, cycling, and swimming. Physical fitness is the body's ability to function effectively when working or doing other things, and still have enough energy to handle or emergencies that may arise. Before planning to do aerobic exercise, namely: the frequency of exercise three to five times every week, exercise intensity 60 - 80\% of maximum heart rate, and duration of exercise $20-60$ minutes.mConclusion: With regular aerobic exercise, blood flow to be smooth and speed up the disposal of metabolic waste substances, so that recovery takes place rapidly, and the person with not experience fatigue after performing the task, and still be able to perform other activities. Benefits of aerobic exercise training is increased physical fitness.
\end{abstract}

Keywords: aerobic exercise, physical fitness.

\begin{abstract}
Abstrak: Latihan olahraga aerobik ialah aktivitas olahraga secara sistematis dengan peningkatan beban secara bertahap dan terus-menerus yang menggunakan energi yang berasal dari pembakaran dengan menggunakan oksigen, dan membutuhkan oksigen tanpa menimbulkan kelelahan.Contoh latihan olahraga aerobic adalah jalan, jogging, lari, bersepeda, dan renang. Kebugaran fisik adalah kemampuan tubuh untuk berfungsi secara efektif ketika bekerja atau melakukan aktivitas lainnya, dan masih memiliki cukup energi untuk menangani atau menghadapi keadaan darurat yang mungkin timbul. Sebelum merencanakan untuk melakukan latihan olahraga aerobik, perlu memperhatikan kriteria-kriteria yang berkaitan dengan takaran latihan, yaitu: frekuensi latihan tiga sampai lima kali setiap minggu, intensitas latihan $60-80 \%$ dari denyut jantung maksimal, dan durasi latihan 20 - 60 menit. Simpulan: Dengan pembuangan zat-zat sisa metabolisme, sehingga pemulihan berlangsung dengan cepat, dan seseorang tidak akan mengalami kelelahan setelah melaksanakan tugas, serta masih dapat melakukan aktivitas lainnya. Manfaat latihan olahraga aerobik ialah kebugaran fisik meningkat.
\end{abstract}

Kata kunci: Latihan olahraga aerobik, kebugaran fisik.

Hari Kesehatan seluruh dunia ke 54 tahun 2002, oleh World Health Organization diperingati dengan tema Fit For Health yang dipusatkan di Brazil dengan tema Move For Health atau Agita Mundo. ${ }^{1}$ Perkataan olahraga mengandung arti adanya sesuatu yang berhubungan dengan peristiwa mengolah raga atau mengolah jasmani. Definisi olahraga ialah segala gerak badan yang dilakukan manusia dengan teknik tertentu untuk membentuk tubuh dengan intensitas, batas waktu dan tujuan tertentu. ${ }^{2,3}$

Olahraga menurut ensiklopedia 
Indonesia adalah gerak badan yang dilakukan oleh satu orang atau lebih yang merupakan regu atau kelompok. ${ }^{4}$ Definisi olahraga dari sudut pandang ilmu faal ialah, serangkaian gerak raga yang teratur dan terencana yang dilakukan seseorang dengan sadar untuk meningkatkan kemampuan funsionalnya, sesuai dengan tujuannya melakukan olahraga. ${ }^{2}$ Latihan didefinisikan sebagai aktivitas olahraga secara sistematis yang dilakukan berulang-ulang dalam jangka waktu lama disertai dengan peningkatan beban secara bertahap dan terus-menerus sesuai dengan kemampuan masing - masing individu, tujuannya adalah untuk membentuk dan mengembangkan fungsi fisiologis dan psikologis. ${ }^{5}$ Latihan adalah proses kerja yang dilakukan secara sistematis dan berkesinambungan. Beban atau intensitasnya semakin hari semakin bertambah agar memberikan rangsangan secara menyeluruh terhadap tubuh. ${ }^{6}$ Latihan olahraga aerobik merupakan aktivitas yang bergantung terhadap ketersediaan oksigen untuk membantu proses pembakaran sumber energy sehingga juga akan bergantung terhadap kerja optimaldari organ-organ tubuh, seperti: jantung, paru-paru, dan juga pembuluh darah untuk mengangkut oksigen agar proses pembakakaran sumber energi dapat berjalan sempurna. Aktivitas ini biasanya merupakan aktivitas olahraga dengan intensitas rendah-sedang yang dapat dilakukan secara terus -menerus dlam waktu cukup lama, seperti: jalan kaki, bersepeda, dan jogging. ${ }^{7}$ Kebugaran secara umum dapat diartikan sebagai kemampuan fisik seorang dalam melakukan kegiatan atau kerja secara efisien tanpa timbul kelelahan yang berarti. ${ }^{8}$ Kebugaran fisik adalah kemampuan tubuh untuk berfungsi secara efektif ketika bekerja atau melakukan aktivitas lainnya, dan masih memiliki cukup energi untuk menangani atau menghadapi keadaan darurat yang mungkin timbul. ${ }^{9}$ Manfaat latihan olahraga aerobik ialah kebugaran kardiorespiratori.

Dengan latihan olahraga aerobik seseorang dapat meningkatkan ambilan oksigen, meningkatkan kapasitas darah untuk mengangkut oksigen, menurunkan denyut nadi saat istirahat maupun saat melakukan aktivitas. Latihan olahraga aerobik juga meningkatkan jumlah kapiler, menurunkan kadar lemak dalam darah, dan meningkatkan enzim pembakar lemak. ${ }^{10}$

\section{LATIHAN OLAHRAGA AEROBIK}

Latihan olahraga aerobik merupakan aktivitas yang bergantung terhadap ketersediaan oksigen untuk membantu proses pembakaran sumber energi, sehingga bergantung pula terhadap kerja optimal dari organ-organ tubuh, seperti: jantung, paru-paru, dan pembuluh darah untuk mengangkut oksigen agar proses pembakaran sumber energi dapat berjalan dengan sempurna. $^{7}$

Metabolisme energi pada latihan olahraga aerobik berjalan melalui pembakaran simpanan lemak, karbohidrat, dan sebagian kecil (kurang dari lima persen) dari pemecahan simpanan protein yang terdapat didalam tubuh untuk menghasilkan adenosine trifosfat. Proses metabolism ketiga sumber energi ini berjalan dengan kehadiran oksigen yang diperoleh melalui proses pernapasan.

Lemak dimetabolisme harus menggunakan oksigen dan proses ini juga membutuhkan karbohidrat agar proses pembakarannya menjadi sempurna sedangkan karbohidrat dapat dimetabolisme tanpa kehadiran oksigen dengan proses glikolisis. ${ }^{7}$ Langkah awal dari metabolism energy lemak adalah melalui proses pemecahan simpanan lemak yang terdapat didalam tubuh (trigliserida). Trigliserida didalam tubuh ini tersimpan didalam jaringan adipose (adipose tissue) dan didalam sel-sel otot (intramuscular triglycerides). Melalui proses lipolysis, trigliserida yang tersimpan dikonversi menjadi asam lemak dan gliserol. Pada proses ini, untuk setiap satu molekul trigliserida terbentuk tiga molekul adam lemak dan satu molekul gliserol. ${ }^{7}$ Kedua molekul yang dihasilkan melalui proses ini akan mengalami jalur metabolism yang berbeda didalam tubuh. Gliserol yang terbentuk masuk ke dalam siklus 
metabolisme untuk diubah menjadi glukosa atau asam piruvat sedangkan asam lemak yang terbentuk dipecah menjadi unit-unit kecil melalui proses B-oksidasi untuk menghasilkan energi didalam mitokondria sel. $^{7}$ Proses B-oksidasi berjalan dengan kehadiran oksigen dan membutuhkan karbohidrat untuk menyempurnakan pembakaran asam lemak. Pada proses ini, asam lemak yang pada umumnya berbentuk rantai panjang yang terdiri dari kurang lebih enam belas atom karbon dipecah menjadi unit-unit kecil yang terbentuk dari dua atom karbon. Tiap unit dua atom karbon yang terbentuk ini mengikat kepada satu molekul KoA untuk membentuk asetil KoA. Kemudian molekul asetil KoA yang terbentuk masuk ke dalam siklus asam sitrat dan diproses untuk menghasilkan energi sama seperti molekul astil KoA yang dihasilkan melalui proses metabolisme energy dari glukosa atau glikogen. ${ }^{7}$

Latihan olahraga aerobik merupakan aktivitas olahraga dengan intensitas rendah hingga sedang yang dilakukan secara terusmenerus, seperti: jalan kaki, lari, bersepeda dan jogging sedangkan latihan olahraga anaerobik merupakan aktivitas dengan intensitas tinggi yang membutuhkan energi secara cepat dalam waktu singkat, namun tidak dapat dilakukan secara terus-menerus dengan durasi lama.

Latihan olahraga anaerobik membutuhkan interval istirahat agar adenosin trifosfat dapat diregenerasi, sehingga dapat melanjutkan kegiatan kembali.Energi yang digunakan oleh tubuh untuk melakukan aktivitas yang membutuhkan energi secara cepat ini diperoleh melalui glikolisis glukosa secara anaerobik, serta melalui hidrolisis fosfokreatin. Proses metabolisme energi secara anaerobik dapat berjalan tanpa kehadiran oksigen. Glikolisis merupakan salah satu bentuk dari metabolisme energi yang dapat berjalan secara anaerobik. ${ }^{7}$ Inti dari proses glikolisis yang terjadi didalam sel sitoplasma adalah mengubah molekul glukosa menjadi asam piruvat, proses ini disertai juga dengan pembentukan adenosin trifosfat. Jumlah adenosin trifosfat yang dihasilkan oleh proses glikolisis ini akan berbeda, bergantung pada asal molekul glukosa. Jika molekul glukosa berasal dari dalam darah, maka dua buah adenosin trifosfat yang dihasilkan sebanyak tiga buah. $^{7}$ Molekul asam piruvat yang terbentuk dari proses glikolisis dapat mengalami proses metabolisme lanjut secara aerobik maupun anaerobik, bergantung pada ketersediaan oksigen didalam tubuh. Pada saat latihan olahraga dengan intensitas rendah, dimana ketersediaan oksigen didalam tubuh cukup besar, molekul asam piruvat yang terbentuk ini diubah menjadi karbon dioksida dan air didalam mitokndria sel. Jika ketersediaan oksigen terbatas didalam tubuh atau pembentukan asam piruvat terjadi secara cepat seperti saat melakukan lari cepat jarak pendek, maka asam piruvat tersebut akan terkonversi menjadi asam laktat. ${ }^{7}$

Sebelum merencanakan untuk melakukan latihan olahraga aerobik perlu memperhatikan kriteria-kriteria yang berkaitan dengan dosis latihan, sebagai berikut: ${ }^{11}$

1. Frekuensi ialah jumlah ulangan latihan yang dilakukan selama satu minggu. Frekuensi latihan olahraga aerobic adalah dua kali, tiga kali, atau enam kali. $^{12}$

2. Intensitas latihan olahraga aerobik diukur dengan cara mengukur denyut jantung maksimal. Intensitas latihan olahraga aerobik adalah enam puluh sampai delapan puluh persen berat ringannya suatu beban latihan. ${ }^{13}$

3. Durasi ialah jangka waktu atau lamanya latihan yang diberikan agar memberikan manfaat. Durasi latihan olahraga aerobik adalah dua puluh sampai enam puluh menit. ${ }^{14}$

4. Jenis latihan: Macam aktivitas fisik dipilih disesuaikan dengan tujuan latihan. Misalnya, bentuk latihan untuk mengembangkan kardiorespirasi ada bermacam-macam seperti: lari, sepeda, jogging, berenang, dan jalan kaki. ${ }^{15}$ Pemberian beban latihan ditanggapi oleh tubuh dalam bentuk respon.

Dosis latihan yang tepat harus 
memperhatikan frekuensi, intensitas, dan durasi, namun dosis latihan yang tidak tepat dan dilakukan secara berlebihan dapat menimbulkan beberapa efek. Efek-efek dari dosis yang tidak tepat dan latihan olahraga aerobik dilakukan secara berlebihan, antara lain: ${ }^{11}$ penurunan berat badan yang berlebihan, kehilangan kelebihan lemak tubuh, peningkatan denyut jantung istirahat, penurunan kekuatan otot, peningkatan denyut jantung submaksimal, nyeri otot kronis, kelelahan, rentan terkena infeksi, insomnia.

\section{KEBUGARAN FISIK}

Komponen-komponen kebugaran yang berhubungan dengan kesehatan, yaitu:

1. Daya tahan jantung paru: merupakan kesanggupan dari sistem jantung, paruparu, dan pembuluh darah untuk bekerja secara optimal saat melakukan aktivitas sehari-hari dalam waktu yang lama tanpa mengalami kelelahan berarti. $^{16}$

2. Kekuatan otot dapat diartikan kemampuan otot atau sekelompok otot dalam melakukan kerja seperti menggerakan anggota tubuh saat berlari, berjalan, dan mengangkat. Kekuatan otot ini dipengaruhi oleh faktor latihan yang teratur dan terencana secara sistematis. ${ }^{17}$

3. Fleksibilitas atau kelenturan ialah luas bidang gerak yang maksimal pada persendian, tanpa dipengaruhi oleh suatu paksaan atau tekanan. ${ }^{18}$

4. Komposisi tubuh ialah perbandingan jumlah lemak yang terkandung didalam tubuh dengan berat badan seseorang.

Komponen kebugaran yang berhubungan dengan keterampilan, yaitu:

1. Kecekatan ialah kemampuan untuk mengubah arah gerak tubuh secara cepat dan tepat.

2. Kelincahan ialah kemampuan seseorang mengubah posisi di area tertentu, dari depan ke belakang, dari kiri ke kanan, atau dari samping ke depan. $^{19}$
3. Keseimbangan ialah kemampuan seseorang mengendalikan organ-organ saraf otot. ${ }^{20}$

4. Koordinasi ialah hubungan harmonis dari berbagai faktor yang terjadi pada suatu gerakan.

5. Daya ledak otot ialah kemampuan maksimal otot yang dapat dihasilkan dalam waktu singkat.

6. Reaksi ialah kemampuan seseorang untuk segera bertindak secepatnya. $^{21}$

7. Kecepatan ialah kapasitas gerak dari anggota tubuh untuk menempuh jarak tertentu dalam waktu sesingkatsingkatnya. ${ }^{22}$

Faktor-faktor yang memengaruhi kebugaran fisik, antara lain: ${ }^{23}$

1. Usia: Pada usia pertumbuhan seseorang akan lebih baik, dikarenakan fungsi organ tubuh akan tumbuh dengan optimal. Sedangkan pada usia dewasa akan terjadi penurunan kebugaran fisik dikarenakan banyak jaringan-jaringan didalam tubuh yang mengalami kerusakan.

2. Jenis kelamin: Sampai pubertas biasanya kebugaran fisik anak laki-laki hamper sama dengan anak perempuan, tetapi setelah pubertas anak laki-laki mempunyai nilai yang lebih besar.

3. Genetik: Kapasitas aerobik maksimal seseorang $\left(\mathrm{VO}_{2} \max \right)$ ditentukan oleh faktor genetik yang berperan pada kapasitas jantung paru, hemoglobin, dan eritrosit.

4. Makanan: Daya tahan tubuh akan berada dalam keadaan optimal bila mengonsumsi makanan tinggi karbohidrat.

5. Rokok: Kadar karbon yang terhisap akan mengurangi kadar volume oksigen maksimal, yang berpengaruh terhadap daya tahan.

Alat ukur yang digunakan untuk menilai kebugaran fisik, serta untuk menentukan standar kebugaran fisik antara lain tes lari 2,4 km dan tes naik turun bangku Harvard (Harvard Step Test). ${ }^{24}$ 


\section{MANFAAT LATIHAN OLAHRAGA AROBIK TERHADAP KEBUGARAN FISIK}

Manfaat bagi jantung ialah jantuntg bertambah besar, sehingga daya tampung lebih besar dan denyut nadi (stroke volume) menjadi kuat. Hal ini terjadi karena saat latihan terjadi peningkatan tuntutan oksigen di otot aktif menjadi meningkat, lebih banyak nutrisi digunakan, dan proses metabolisme dipercepatkan, serta menghasilkan sisa metabolisme. Terjadi respon, seperti peningkatan kontraktilitas miokard, peningkatan curah jantung yang juga berdampak pada tekanan darah sistolik meningkat, peningkatan denyut jantung, peningkatan tekanan darah dan respon perifer termasuk vasokonstriksi umum pada otot-otot dalam keadaan istirahat, ginjal, hati, limpa, dan daerahdaerah planknikus ke otot-otot kerja. Setelah latihan secara teratur, terjadi penurunan denyut nadi saat istirahat. Efisiensi kerja dari tiap denyut jantung (stroke volume), sehingga terjadi penurunan frekuensi denyut jantung yang ditandai dengan penurunan denyut nadi saat istirahat. $^{25}$

Manfaat bagi pembuluh darah, pembuluh darah bertambah elastis karena berkurangnya timbunan lemak akibat cadangan lemak lebih banyak dibakar. Efek positif pada keadaan tersebut membuat kadar LDL atau Low Density Lipoprotein akan menurun, kadar HDL atau High Density Lipoprotein meningkat, sehingga berat badan relatif proporsional. Elastisitas pembuluh darah bertambah, karena adanya penambahan kontraktilitas otot di dinding pembuluh darah. ${ }^{25}$ Manfaat untuk paru, elastisitas paru bertambah, sehingga kemampuan paru-paru untuk berkembang kempis menjadi bertambah. Selain itu, jumlah alveoli yang aktif bertambah. ${ }^{25}$

\section{SIMPULAN}

Latihan olahraga aerobik ialah aktivitas olahraga secara sistematis dengan peningkatan beban secara bertahap dan terus menerus yang menggunakan energi yang berasal dari pembakaran dengan menggunakan oksigen, dan membutuhkan oksigen tanpa menimbulkan kelelahan.

Dengan latihan olahraga aerobik teratur, aliran darah menjadi lancer dan mempercepat pembuangan zat-zat sisa metabolism sehingga pemulihan berlangsung dengan cepat, dan seseorang tidak akan mengalami kelelahan setelah melaksanakan tugas, serta masih dapat melakukan aktivitas lainnya.

\section{SARAN}

Disarankan untuk melakukan latihan olahraga aerobik untuk menjaga dan meningkatkan kebugaran fisik, maka kita harus melakukannya dengan baik dan benar agar terhindar dari kelelahan.

\section{DAFTAR PUSTAKA}

1. Karim F. Panduan Kesehatan Olahraga Bagi Petugas Kesehatan Jakarta. Departemen Kesehatan. 2002.

2. Nasution M. Pengaruh Hormon TIroid Dalam Aktivitas Olahraga Aerobik. KEMAS. Volume 2. Semarang. 2007.

3. Sumartiningsih S. Variasi Tipologi dan Prestasi Atlet (Ditinjau dari Atlet Jawa TImur pada PON XVII). Jurnal Media Ilmu Keolahragaan Indonesia. Vol.1. Semarang. 2011.

4. Purwanto DD. Pengertian Olahraga\& Kebugaran Jasmani. Diunduh dari: http://www.slideshare.net/dimaswi/pen gertian-olahraga-kebugaranjasmani.Diakses pada tanggal 21 Februari 2012.

5. Muhamad Maqsalmina. PENGARUH LATIHAN AEROBIK TERHADAP PERUBAHAN $\mathrm{VO}_{2}$ MAX PADA SISWA SEKOLAH SEPAKBOLA TUGU MUDA SEMARANG USIA 12-14 TAHUN. SEMARANG. 2007.

6. Wordpress. Latihan Kebugaran. Diunduh dari: http://www.google.com. Diakses pada tanggal 21 Februari 2012.

7. Metabolisme Energi Tubuh \& Olahraga. Sports Sciene Brief. Vol.1. Jakarta.2007.

8. Aziz H. Pengertian Kebugaran Jasmani (Physical Fitness) dan Latihan Kebugaran. Diunduh dari: http://duniakebugaran.blogspot.com/20 11/11/pengertian-kebugaran-jasmaniphysical.html. Diakses pada tanggal 21 
Februari 2012.

9. Tips Bugar: Mengenal 5 Komponen Kebugaran Fisik. Diunduh dari: http:// www.amazine.co/3374/tips-bugarmengenal-5-komponen-kebugaranfisik/. Diakses pada tanggal 21 Februari 2012.

10.Media Indonesia. Sehat Kebugaran, Bagaimana Mencapainya. Diunduh dari: http:// groups.or.id/ppermail/kb/2004August/001650.html. Diakses pada tanggal 19 Desember 2011.

11.Sudarsono NC. Kebugaran. Diunduh dari: http:// www.google.com. Diakses pada tanggal: 21 Februari 2012.

12.Tegartia's Blog. LATIHAN KEBUGARAN JASMANI. Diunduh dari: http://www.LATIHANKEBUGARAN JASMANI_Tegartia's Blog.htm. Diakses pada tanggal 21 Februari 2012.

13.Swasta EB. Pentingnya Kebugaran Jasmani Bagi Guru Profesional. Diakses dari: http://staff.uny.ax.id/sites/default/files/ PENTINGNYA\%20KEBUGARAN20 \%JASMANI.pdf. Diunduh pada tanggal 21 Februari 2012.

14.Ambarkati AY. Takaran Olahraga Yang Benar dan Aman. Diunduh dari http://olah-ragaindonesia.blogspot.com/2012/04/takara n-olahraga-yang-benar-dan-aman.html. Diakses pada tanggal 3 Mei 2012.

15.UNY. Latihan Aerobik. Diunduh dari http://eprints.uny.ac.id/7715/3/BAB\%2 02\%20-\%2008603141034.pdf. Diakses pada tanggal 21 Februari 2012.

16.SatyaWI. Kebugaran Jasmani Dalam Mendukung Kinerja. Vol 4. Jurnal IQRA, Ilmu Kependidikan dan Keislaman.2008. h. 211-222.

17.Susnadi. Kesegaran Jasmani. Diunduh dari http:materipenjasorkes.blogspot.com/2 012/07/kesegaran-jasmani.html.

Diakses pada tanggal 3 Agustus 2013.

18.Andreacha. Komponen Kebugaran

Jasmani. Diunduh dari

http://olahragaancha.blogspot.com/201

1/10/komponen-kebugaran-

jasmani.html. Diakses pada tanggal 21

Februari 2012.

19.Anggaway. Komponen Kebugaran Jasmani. Diunduh dari http://anggaway89.wordpress.com/201 0/08/24/komponen-kesegaran-jasmani/. Diakses pada tanggal 21 Februari 2012.

20.Saifur. Komponen Kesegaran Jasmani. Diunduh dari http://saifurss07.wordpress.com/2010/0 6/03/komponen-kesegaran-jasmani/. Diakses pada tanggal 21 Februari 2012.

21.Berthae. Komponen Kesegaran Jasmani. Diunduh dari http://berthae.wordpress.com/2013/07/ komponen-kebugaran-jasmani/.

Diakses pada tanggal 21 Februari 2012.

22.Riki A. Komponen Kebugaran Jasmani. Diunduh dari: http://rikimakaro.blogspot.com/2013/0 7/komponen-kebugaran-jasmani.html. Diakses pada tanggal 3 Agustus 2013.

23.Rizalfreestyler's Blog. Kebugaran Jasmani. Diunduh dari: http://rizalfreestyler.wordpress.com/20 10/09/04/47/. Diakses pada tanggal 21 Februari 2012.

24.Estu M. Kebugaran Fisik. Diunduh pada http://www.scribd.com/doc/79740669/ kebugaranfisik. Diakses pada tanggal 21 Februari 2012.

25.Kushartanti BMW. Kebugaran Jasmani dan Produktivitas Kerja. Diunduh dari http://okleqs.files.wordpress.com/2011/ 09/kebugaran-jasmani-danproduktivitas-kerja.pdf. Diakses 22 Februari 2012. 